\title{
USO DE PIRROLIDINODITIOCARBAMATOS DE MANGANÊS(II) E VANADILA NA PREPARAÇÃO E APLICAÇÃO DE ELETRODOS DE PASTA DE CARBONO MODIFICADOS
}

\author{
Aline Segnini
}
Dissertação apresentada ao Instituto de Química de São Carlos, da Universidade de São Paulo, para a obtenção do título de Mestre em Ciências - Química Analítica.

Orientador: Prof. Dr. Éder Tadeu Gomes Cavalheiro

São Carlos

2003 
Aos meus pais, pela oportunidade e apoio nas horas mais difíceis

A Deus, por tudo... 


\section{AGRADECIMENTOS}

> Ao Prof. Dr. Éder Tadeu Gomes Cavalheiro, pela orientação e confiança.

$>$ Ao Fernando C. Moraes, pelo apoio, incentivo e por ter contribuído em grande parte nesse trabalho.

> À Andréa Couto, pelo auxílio com os complexos de ditiocarbamatos.

> A todos os colegas do laboratório: Fabi, Márcio, Toni, Rogerinho, João, Estrela, Priscila, Rita, Ju, Graziela, Aline "2", Glima, Luizinho, Mônica e Toninho, pelos bons momentos.

> Ao Função, pela co-orientação, no início deste trabalho.

$>$ Ao Leandro, pelo carinho especial.

$>$ Enfim, à minha família, aos meus amigos, e aos que torceram por mim. 